\title{
Fish consumption on the Amazon: a review of biodiversity, hydropower and food security issues
}

\author{
A. Begossi ${ }^{a, b, c *}$, S. V. Salivonchyk ${ }^{d}$, G. Hallwass ${ }^{c, e}$, N. Hanazaki ${ }^{c, f}$, P. F. M. Lopes ${ }^{c, g}$, \\ R. A. M. Silvano ${ }^{c, h}$, D. Dumaresq $q^{i}$ and J. Pittock
}

aPrograma de Capacitação de Pescadores Artesanais - CAPESCA, Núcleo de Estudos e Pesquisas em Alimentação - NEPA, Universidade Estadual de Campinas - UNICAMP, Rua Albert Einstein, nº 291, CEP 13083-852, Campinas, SP, Brasil

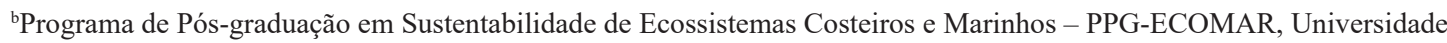
Santa Cecília - UNISANTA, Rua Oswaldo Cruz, n 277, Boqueirão, CEP 11045-907, Santos, SP, Brasil

${ }^{\mathrm{c}}$ Fisheries and Food Institute - FIFO, Rua Oswaldo Cruz, n⿳ 277, Boqueirão, CEP 11045-907, Santos, SP, Brasil

${ }^{\mathrm{d}}$ Institute for Nature Management, National Academy of Sciences of Belarus, 10 Fr. Skaryna Street, Minsk, 220114, Minsk, Belarus

'Universidade Federal do Oeste do Pará - UFOPA, Rodovia PA-254, n 257, CEP 68270-000, Oriximiná, PA, Brasil

fDepartmento de Ecologia e Zoologia, Universidade Federal de Santa Catarina - UFSC, Campus Universitário, Córrego Grande, CEP 88040-900, Florianópolis, SC, Brasil

${ }^{\mathrm{g}}$ Departamento de Ecologia, Universidade Federal de Rio Grande do Norte - UFRN, Av. Sen. Salgado Filho, no 3000 , Lagoa Nova, CEP 59064-741, Natal, RN, Brasil

hPrograma de Pós-graduação em Ecologia, Departamento de Ecologia, Universidade Federal do Rio Grande do Sul UFRGS, CP 15007, CEP 91501-970, Porto Alegre, RS, Brasil

${ }^{\mathrm{i}}$ Fenner School of Environment and Society, The Australian National University - ANU, B141, B48, B48A, Linnaeus Way, Acton ACT 2601, Canberra, Australia

*e-mail: alpinab@uol.com.br

Received: October 16, 2017 - Accepted: November 22, 2017 - Distributed: May 31, 2019

(With 1 figure)

\begin{abstract}
The lack of knowledge about the majority of fish species harvested in Amazonian small-scale fisheries, in association with impacts from hydroelectric power plants, may lead to biodiversity loss and a decrease in the protein food supply for riverine Amazonians. This study uses existing datasets on fisheries and riverine developmental projects to infer effects associated with fish losses where actual data and outcomes are not available. The targeted fish species' status may be regarded as either threatened or there being no knowledge of their conservation requirements, biology or ecology. Among the 90 Amazonian fish species that are the most important for the diet of the riverine fishers, $78 \%$ are not assessed or their biological information is unknown, according to the IUCN Red List. Consequently, the effects created by the thoroughly disregarded trade-off between energy generation and food security in the planning of Amazonian land use have been worsened by the lack of biological and ecological information on fish species.
\end{abstract}

Keywords: small-scale fisheries, Amazon River, caboclos, diet, food security.

\section{Consumo de Peixes na Amazônia: uma revisão sobre biodiversidade, hidrelétricas e segurança alimentar}

\section{Resumo}

A falta de conhecimento sobre a maioria das espécies alvo de comunidades pesqueiras da Amazonia, associada ao impacto das hidrelétricas pode levar ao descréscimo da biodiversidade e na disponibilidade de proteína para os ribeirinhos da Amazônia. As espécies alvo são vulneráveis ou pouco conhecidas em sua biologia ou ecologia. Dentre 90 espécies de peixes importantes na dieta dos ribeirinhos, $78 \%$ não são estudadas ou sua biologia é desconhecida, de acordo com a lista da UICN. Dessa forma, os efeitos criados pela negligenciada relação de custo e benefício entre a produção de energia e a segurança alimentar no planejamento da Amazônia tem ainda piorado a situação de desconhecimento sobre as espécies de peixes.

Palavras-chave: comunidades pesqueiras artesanais, Rios da Amazônia, caboclos, dieta, segurança alimentar. 


\section{Introduction}

The Amazon River basin is one of the most biodiverse basins in the world for freshwater species, being, for instance, a known habitat for 2,320 fish species, including 1,488 endemic ones (Abell et al., 2008; Winemiller et al., 2016). Historically, these rich waters have provided fish that help maintain ecological, cultural and economic aspects of Amazonian livelihoods (Begossi and Braga, 1992; Begossi, 2014; Begossi et al., 2004, 2012a,b,c; Hallwass et al., 2011; Hallwass and Silvano, 2016). Most Amazonian fishing is done by small-scale fishers, predominantly from the Caboclo culture (descendants of indigenous Brazilians, Portuguese colonizers and immigrants from the Northeastern Brazil). Many investigations have focused on the Caboclo's anthropology and ecology, such as the classical studies by Moran (1996), Nugent (1993), and Wagley (1974).

Caboclo fishers' diets rely heavily on fish protein, and their livelihoods on the supply of fish to local and regional markets (Silva and Begossi, 2009; Isaac et al., 2008; Sarti et al., 2015). Therefore, Caboclo fishers affect and are affected by the availability of freshwater resources and by fish diversity. The observed decline of fishing resources, caused by pollution, habitat destruction, overfishing and river dams for hydropower projects (Pauly et al., 2002; Welcomme et al., 2010; Hallwass et al., 2013; Winemiller et al., 2016), will increase food insecurity of fish dependent communities. Such a decline has already been observed in African countries (Mcclanahan et al., 2015).

Specifically, hydropower dam construction is rapidly expanding in major river basins around the globe, as countries with emerging economies seek to supply their energy demands without the use of fossil fuels (Zarfl et al., 2014; Winemiller et al., 2016). For instance, more than 450 new dams are under construction or proposed in the Amazon, Congo and Mekong river basins (Winemiller et al., 2016). Throughout the Amazon River Basin there are 416 hydroelectric plants operating or under construction, with another 334 proposed or planned (Winemiller et al., 2016). The Brazilian plan for energy production alone encompasses 58 hydroelectric plants on the largest Amazonian rivers (Kahn et al., 2014).

Besides the impacts caused by the construction and functioning of hydroelectric dams themselves, the electricity transmission networks also create biodiversity impacts by increasing the development of roads, which are the key driver of deforestation in the Amazon (Fearnside, 2015). However, there is little sign that such concerns are being considered by development agencies. For example, the Brazilian government stated the intention to significantly increase electricity grid interconnections for energy distribution (Molle et al., 2010) and to provide additional $10,632 \mathrm{MW}$ of installed generation capacity through future dams by 2023 (Tolmasquim, 2007).

There are many well-known negative consequences of dam development, including: displacement of people; deforestation due to flooding and increased road access for other developments; changes in waterflow, nutrients and sediments impacting downstream terrestrial and aquatic ecosystems including farmlands; and loss of fish (Fearnside, 1999, 2004, 2016; Molle et al., 2010; Orr et al., 2012; Hallwass et al., 2013; Tolmasquim, 2014; Benchimol and Peres, 2015; Winemiller et al., 2016). Dam impacts on aquatic fauna, including fish, result in the blockage of migratory routes essential for the life cycle of many fish species, fragmentation of river connectivity, alteration of physical-chemical structure of the river causing changes in fish communities, as well as local extinctions and a reduction in the abundance of fish species (Petrere Junior, 1989; Zhong and Power, 1996; Ponton and Vauchel, 1998; Barthem et al., 1991; Merona et al., 2001; Gehrke et al., 2002; Petesse and Petrere Junior, 2012; Hallwass et al., 2013).

Many of these impacts are not correctly identified in impact assessment reports, and if identified, decision-makers often ignore negative implications of proposed hydropower developments for reasons of corruption, culture or politics (Fearnside, 1999; Solarte et al., 2008; Isaac et al., 2015; Winemiller et al., 2016). Even in the relevant literature, the impacts of hydroelectric plants on riverine fishing communities are almost absent. One approach to identifying the impacts on such riverine peoples is by considering the changes to the fish fauna, the possible changes in peoples' selective methods of fishing and on their food intake. For example, in the Araguaia-Tocantins system, a heavily impacted region since the 1970's, the livelihoods of about 44,000 people are expected to be affected by the 27 planned dams (Carneiro and Souza, 2009).

Besides developmental projects, overfishing has also affected the biodiversity of various aquatic ecosystems (Pauly et al., 2002; Jackson et al., 2001; Myers and Worm, 2003; Worm et al., 2006). In marine costal areas for instance, studies based on interviews with older fishers indicate that fish catch was higher in the past (Pauly, 1995; Ainsworth et al., 2008). Historical and archaeological studies have shown the occurrence of higher fish abundance in the remote past, which highlights the importance of fish to ancient populations (Pinnegar and Engelhard, 2007; Prestes-Carneiro et al., 2015). One archaeological study indicated that fish fauna accounted for more than $75 \%$ of the vertebrate species recovered in an ancient (750 to 1020 A.D.) settlement of indigenous populations in the Central Brazilian Amazon (Prestes-Carneiro et al., 2015). In spite of long lasting importance of fish to ensure food security of human populations (Bené et al., 2015, 2016; Mcclanahan et al., 2015), few studies have shown a link of fish species consumption to food security. Small-scale fisheries (SSFs) ensure income for millions of people worldwide, especially in developing countries (Andrew et al., 2007; De Graaf et al., 2011). In such countries, while fishing may not guarantee large cash incomes, it helps prevent livelihoods of deprivation and poverty (Bené, 2006). Besides, most of the fish caught by SSFs is for direct human consumption (food security) with little discard and reduced costs compared to large-scale 
commercial fisheries (Pauly, 2006). However, SSFs remain largely underreported and underestimated (Welcomme et al., 2010; De Graaf et al., 2011; Bartley et al., 2015).

Freshwater fish catch is about one seventh of that of marine fish globally (2013) (Food and Agriculture Organization, 2013a). Fish provide $6.5 \%$ of global protein, although in Brazil this figure is estimated at only 2.9\% (2011) (Food and Agriculture Organization, 2011). In Brazil, fisheries provide $62 \%$ (2013) of the fish supply (Food and Agriculture Organization, 2013b), the remaining being provided by aquaculture. Yet for Amazonians fish comprise a major portion of their diet. The average quantity of fish eaten in the Amazon is 462 g.person ${ }^{-1}$. day ${ }^{-1}$ or 169 kg.person ${ }^{-1}$.year ${ }^{-1}$ (Isaac et al., 2015). (Table 1). Further, in places such as the Lower Amazon ( $\mathrm{n}=586$ records of meals), Lower Purus $(n=341)$, and Trombetas $(n=850)$ while a wide variety of animal protein sources, such as cayman, canned meat, beef, game meat, chicken egg, pork, poultry, turtle and turtle egg were recorded, fish correspond to $64-76 \%$ of the weight of the animal protein intake (Isaac et al., 2015).

In the Negro River, fish account for $75 \%$ of the animal protein locally extracted or farmed and for $57 \%$ of the total animal protein consumed (in 482 meals recorded) (Silva and Begossi, 2009). However, within nutrition transitional systems, there are records of people starting to acquire and rely on processed and imported food rather than fish. Such a transition has been observed, for example, at Ituqui Island (Amazon River, Santarém, Pará State) (Food and Agriculture Organization, 2013a) and at the Solimões River (Dugan et al., 2002). Given the value of fish in the diets of local people and the risks associated to transitions to other types of food, it is important to raise the question of whether there is enough knowledge to manage Amazonian fish species sustainably.
In this study, we investigate the possible impacts of current fish loss on the food security of riverine inhabitants and livelihoods of small-scale fishers in the Brazilian Amazon. We focus on the rivers Juruá (123), Negro (66), and Araguaia-Tocantins sub-system (328) (Figure 1, Table 1). Our main goal is to conduct a meta-analysis of data collected over 11 years for fish species preferred and consumed by scattered riverine small-scale inhabitants of the Amazon ( $\mathrm{n}=517$ interviews) (Figure 1), to investigate potential relationships between the fish species consumed and those that are threatened by dam developments.

\section{Methods}

This study was based on a compilation of interviews on riverine communities in the Brazilian Amazon (Araguaia, Tocantins, Negro and Jurua rivers, $n=517$ interviews, Figure 1) at different periods from 1987 to 1998. These studies were conducted in earlier projects coordinated by one of the authors $(\mathrm{AB})$ and data are deposited in archives at the Fisheries and Food Institute (Appendix A). Parts of these data have been previously published (Begossi and Garavello, 1990; Begossi and Braga, 1992; Begossi and Figueiredo, 1995; Begossi et al., 1999, 2012a,b,c; Silva and Begossi, 2009).

For this study, we compiled data about the first two items cited by fishers when they were asked about the fish species they consumed the most, referred herein respectively as "F1 (fish most consumed) and F2 (second most consumed fish, Table 2). Details of the methods and of fish taxonomic identification, along with other information of the areas and of the communities studied can be found in previous studies (Begossi and Garavello, 1990; Begossi and Braga, 1992; Begossi and Figueiredo, 1995; Begossi et al., 1999,

Table 1. Fish consumption at some Amazonian localities according to the literature. All data shown in the references converted to grams/per capita/day.

\begin{tabular}{|c|c|c|c|}
\hline $\begin{array}{l}\text { Fieldwork } \\
\text { Date }\end{array}$ & Grams per capita day & Locality & Reference \\
\hline 1993-1995 & 369 & Lower Amazon Monte Alegre & Cerdeira et al. (1997) \\
\hline 1992-1994 & 550 & $\begin{array}{l}\text { Low Solimões/High Amazon region } \\
\text { Pesqueiro } \\
\text { Paciência } \\
\text { Aruanã } \\
\text { Marimbá }\end{array}$ & Batista et al. (1998) \\
\hline \multirow[t]{3}{*}{ 1991-1993 } & 243 & $\begin{array}{c}\text { Madeira River } \\
180 \mathrm{~km} \text { from Porto Velho }\end{array}$ & $\begin{array}{l}\text { Boischio and Henshel } \\
\qquad(2000)\end{array}$ \\
\hline & $\begin{array}{c}137 \\
\text { [4.1 kg.hab.month] }\end{array}$ & $\begin{array}{l}\text { Lower Tocantins } \\
\text { Ituquara village }\end{array}$ & Mérona et al. (2001) \\
\hline & $\begin{array}{c}155 \\
\text { [4.6 kg.hab.month] }\end{array}$ & & $\begin{array}{c}\text { Shrimpton and Giugliano } \\
\text { (1979) }\end{array}$ \\
\hline 1981-1982 & $\begin{array}{c}98 \text { [35.7 kg.hab.year] } \\
45 \text { [ (124 grams per capita day) } \\
52 \text { (143 grams per capita day) } \\
7.0 \text { (19 grams per capita day) } \\
7.3 \text { (20 grams per capita day) }\end{array}$ & $\begin{array}{c}\text { Tocantins } \\
\text { Cametá } \\
\text { Mocajuba } \\
\text { Ituquara } \\
\text { Tucuruí } \\
\text { Marabá }\end{array}$ & $\begin{array}{l}\text { Mérona et al. (2010) } \\
\text { [The Tucuruí and Marabá sites are upstream } \\
\text { of the dam]. }\end{array}$ \\
\hline
\end{tabular}




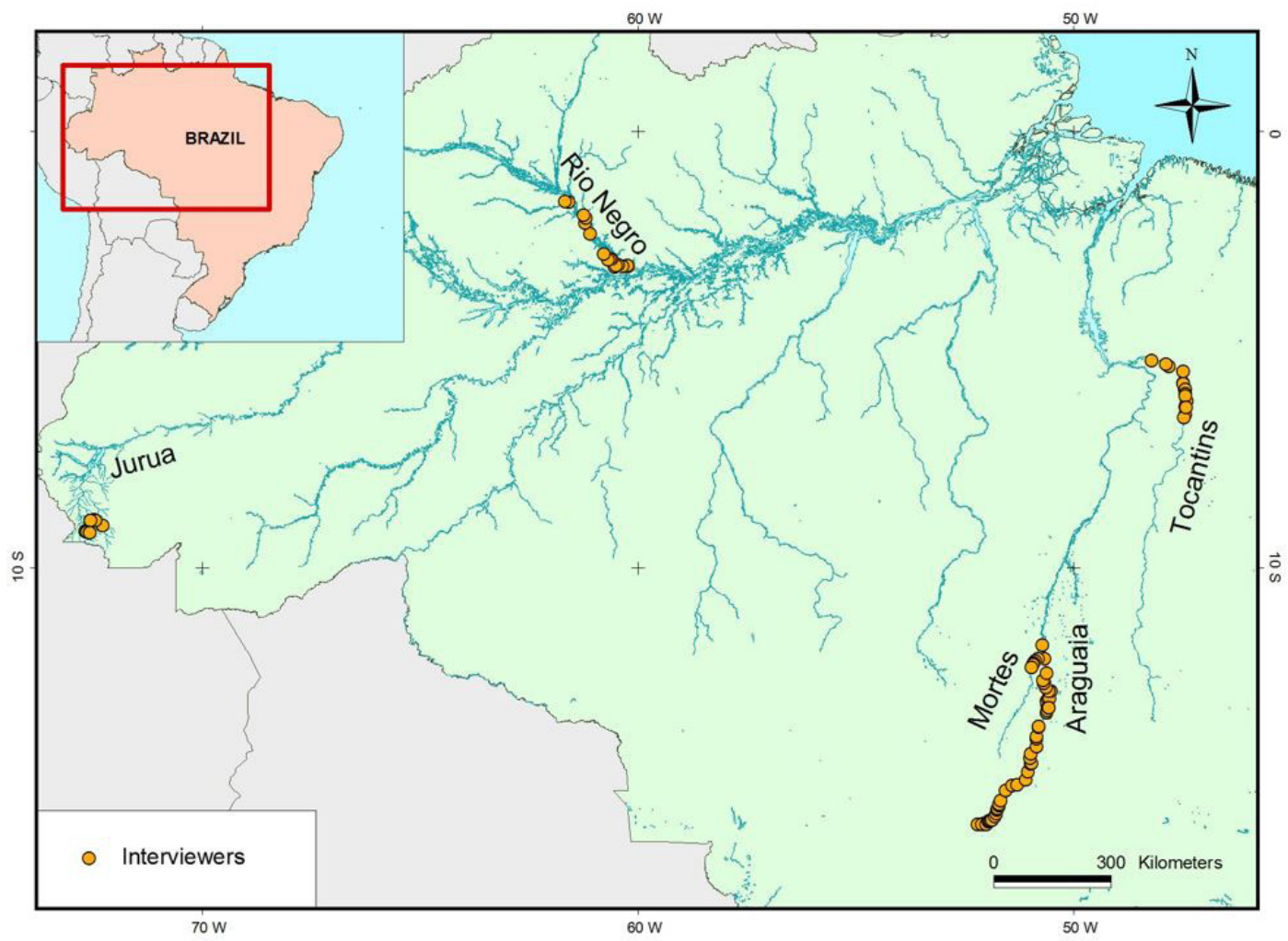

Figure 1. Brazilian Amazon showing the locations of interviews with riverine small-scale fishers (Caboclos).

Table 2. The most important fish cited as consumed by Amazonian riverine families. Results from interviews with Amazon small-scale riverine fishers (see Table 3 for scientific names of fish species) ( $10 \%$ citations or more); $n=$ number of interviews; $\mathrm{F} 1=$ fish cited first in interviews; $\mathrm{F} 2=$ fish cited second in interviews.

\begin{tabular}{|c|c|c|c|c|c|}
\hline Amazonian rivers/Fish & $\begin{array}{c}\begin{array}{c}\text { ARAGUAIA \& MORTE } \\
\text { n=97 }\end{array} \\
\end{array}$ & $\begin{array}{c}\text { TOCANTINS } \\
\mathrm{n}=\mathbf{2 3 1}\end{array}$ & $\begin{array}{c}\text { NEGRO } \\
n=66\end{array}$ & $\begin{array}{c}\text { JURUA } \\
\mathbf{n}=123\end{array}$ & $\begin{array}{c}\text { TOTAL } \\
\mathbf{n}=\mathbf{5 1 7}\end{array}$ \\
\hline Mandi & $26(\mathrm{~F} 1)$ & $23(\mathrm{~F} 2)$ & & $\begin{array}{l}31(\mathrm{~F} 1) \\
30(\mathrm{~F} 2)\end{array}$ & $\begin{array}{l}16(\mathrm{~F} 1) \\
19(\mathrm{~F} 2)\end{array}$ \\
\hline Tucunare & $\begin{array}{l}23(\mathrm{~F} 1) \\
12(\mathrm{~F} 2)\end{array}$ & & $\begin{array}{l}23(\mathrm{~F} 1) \\
20(\mathrm{~F} 2)\end{array}$ & & \\
\hline Piranha & $15(\mathrm{~F} 1)$ & & $16(\mathrm{~F} 2)$ & & \\
\hline Piau & $20(\mathrm{~F} 2)$ & $12(\mathrm{~F} 2)$ & & & \\
\hline Curimata & & $52(\mathrm{~F} 1)$ & & & $24(\mathrm{~F} 1)$ \\
\hline Branquinha & & $13(\mathrm{~F} 2)$ & & & \\
\hline Pacu & & $11(\mathrm{~F} 2)$ & $\begin{array}{l}17(\mathrm{~F} 1) \\
16(\mathrm{~F} 2)\end{array}$ & & \\
\hline Jaraqui & & & $\begin{array}{l}29(\mathrm{~F} 1) \\
14(\mathrm{~F} 2)\end{array}$ & & \\
\hline Cara & & & $\begin{array}{l}11(\mathrm{~F} 1) \\
12(\mathrm{~F} 2)\end{array}$ & & \\
\hline Bode & & & & $\begin{array}{l}51(\mathrm{~F} 1) \\
15(\mathrm{~F} 2)\end{array}$ & $12(\mathrm{~F} 1)$ \\
\hline Surubim & & & & $13(\mathrm{~F} 2)$ & \\
\hline
\end{tabular}

2012a,b,c, 2017; Silva and Begossi, 2009). We assessed the current conservation status of the most cited fish at the IUCN website and at the latest Brazilian Red List, published in November 2014 (IUCN, 2014).

\section{Results}

From the 517 interviews, the fish most cited as consumed in the Amazonian rivers Araguaia and Mortes, Tocantins, Jurua and Negro were Curimata (Prochilodus nigricans) 
and Mandi (Pimelodella, Pimelodus, among other spp.). Tucunaré (Cichla spp.) was important in Araguaia, Mortes and Negro, Jaraqui (Semaprochilodus spp.) was important at the Negro River, and Bode (species of Loricariidade) was important at the Jurua river and its tributaries (Table 2). In another set of interviews in 1987-1988 at the Tocantins river banks ( $\mathrm{n}=233$ interviews) 65 fishers mentioned that Pacu-manteiga (Mylossoma duriventre), an important local fish consumed, decreased in abundance due to the Tucuruí dam.

The IUCN Red List includes 90 species of the 95 species that were cited as the most important by the riverine fishers. Most of them (78\%) have not been assessed and 10\% are of least concern (NA) (Table 3). Therefore, we have almost no knowledge on the conservation status of the most important fish for the food security of Amazonian fishers.

\section{Discussion}

Our results highlighted the almost complete lack of knowledge on freshwater fish important for the food security of Amazonian people. This knowledge gap about the vulnerability of fish can negatively affect and compromise the food security of those Amazonian human populations who highly depend on fish as a source of protein (Batista et al., 1998; Isaac and Almeida, 2011; Begossi et al., 2012b; Lopes et al., 2015). Capture fisheries improve nutrition and food security, besides reducing poverty, in tropical developing countries (Bené et al., 2016). A decrease in the supply of fish as a food source may have indirect consequences for these populations, their livelihoods and their biodiversity rich ecosystems. In Brazil, the food habits of riverine people can change, by including more processed and industrialized items, such as chicken nuggets, pasta, canned meat, among others. Such food items may be nutritionally poor and create a dependence on external food sources (Silva and Begossi, 2009). A decrease in the supply of fish as a food source may increase the use of land for agriculture and hence the rate of deforestation (Orr et al., 2012). This would not only threaten the terrestrial biodiversity but could also exacerbate the current conflicts between fishers and managers of protected tropical forests (Lopes et al., 2013; Begossi et al., 2011). Of particularly interest here are the contrasting cases of the Negro and Araguaia rivers. In the Negro River (52 meals), the reported consumption of animal protein showed that locally caught fish responded for $75 \%$ of their diet, whereas in Araguaia fish responded for only $10 \%$ of all animal protein consumed (Begossi et al., 2000).

The increased exploitation of large, slow-growing and more vulnerable fish species has caused drastic reduction in the populations or even local extinction of these fish, and they tend to be replaced by less valuable and smaller fish in multi-species fisheries (Welcomme, 1999). This pattern of sequential overfishing in tropical fisheries, which is usually driven by an increase demand for fish, have been described as the 'fishing down' process in freshwaters (Welcomme, 1999; Welcomme et al., 2010), and as 'fishing down the food web' in marine ecosystems (Pauly et al.,
1998). 'Fishing down' implies a major reduction in the size of the fish caught (either smaller species or smaller individuals of the same species) (Welcomme et al., 2010). The 'fishing down the food web' implies an overall decrease in the mean trophic level of exploited fish, as larger piscivorous are depleted (Pauly et al., 1998, 2002), although recent evidence has indicated that the sequential overfishing can be more strongly related to the net value of fishing resources than the trophic level of captured species (Sethi et al., 2010).

Ancient Amazonian indigenous people consumed at least 37 taxa of fish species. The larger fish species consumed by these ancient populations (Pirarucu, Arapaima gigas, and Tambaqui, Colossoma macropomum) (Prestes-Carneiro et al., 2015) are currently considered overfished in some regions of the Amazon (Smith, 1985; Garcia et al., 2009; Castello et al., 2013). On the other hand, small fish, such as Mandi, Acari (or Bodes, Loricariidae), Jaraqui, Curimatá, Piau and Tucunaré, were consumed in lower frequencies by the ancient Amazonians (Prestes-Carneiro et al., 2015) (Table 1). The change in the main fish species consumed over time indicates a reduction in the availability and abundance of the large and preferred fish species, which can lead to vulnerability in the food security of riverine peoples who depend on fish for protein intake. The larger fish usually provide more assimilated energy (more biomass) and comparatively demand less processing time to be consumed (fewer or larger spines), tending to be thus more valuable and preferred by fishers (Begossi et al., 2012b).

Governmental plans assigned to protected areas are often in conflict with fish biology researchers, fishery participants and fishers. Furthermore, most of the existing protected areas in Brazil in general (Lopes et al., 2013) or in the Brazilian Amazon (Castello et al., 2013, Junk et al., 2007) have been planned for the protection of terrestrial ecosystems, and have not properly considered for the protection of aquatic biodiversity, fishing resources and local fishing communities. Besides, recent political initiatives by the Brazilian Government (Brazilian Red List and spawning closed seasons) (Pinheiro et al., 2015), might affect threatened species and species where knowledge is almost absent (Table 3). In Brazil, the migratory fish such as Jaraqui (Semaprochilodus spp.), Matrinchã (Brycon sp.), Dourada (Brachyplatystoma rousseauxii), and Filhote (Brachyplatystoma filamentosum) may be increasingly threatened by the construction of dams in the upstream reaches of large rivers (Barthem et al., 1991; Hallwass et al., 2013; Hallwass and Silvano, 2016; Winemiller et al., 2016).

To reverse the observed trend of increasing threats to fish and fishers, we suggest that more attention be devoted to fisheries management and conservation agendas to protect and manage those often neglected fish that are an important food source. This may be achieved by working together and cooperating with the fishers themselves, who have detailed knowledge about fish biology (Silvano et al., 2006, 2008; Silvano and Begossi, 2012; Leite and Gasalla, 2013), and can help to protect fish stocks through co-management 
Table 3. Conservation status of fish consumed in coastal (Atlantic Forest) and inland (Amazon Forest) areas of Brazil [partial information published (Part of this material previously published (Winemiller et al., 2016; Begossi, 2014; Hallwass et al., 2011; Pinnegar and Engelhard, 2007; Prestes-Carneiro et al., 2015; Béné et al., 2015).

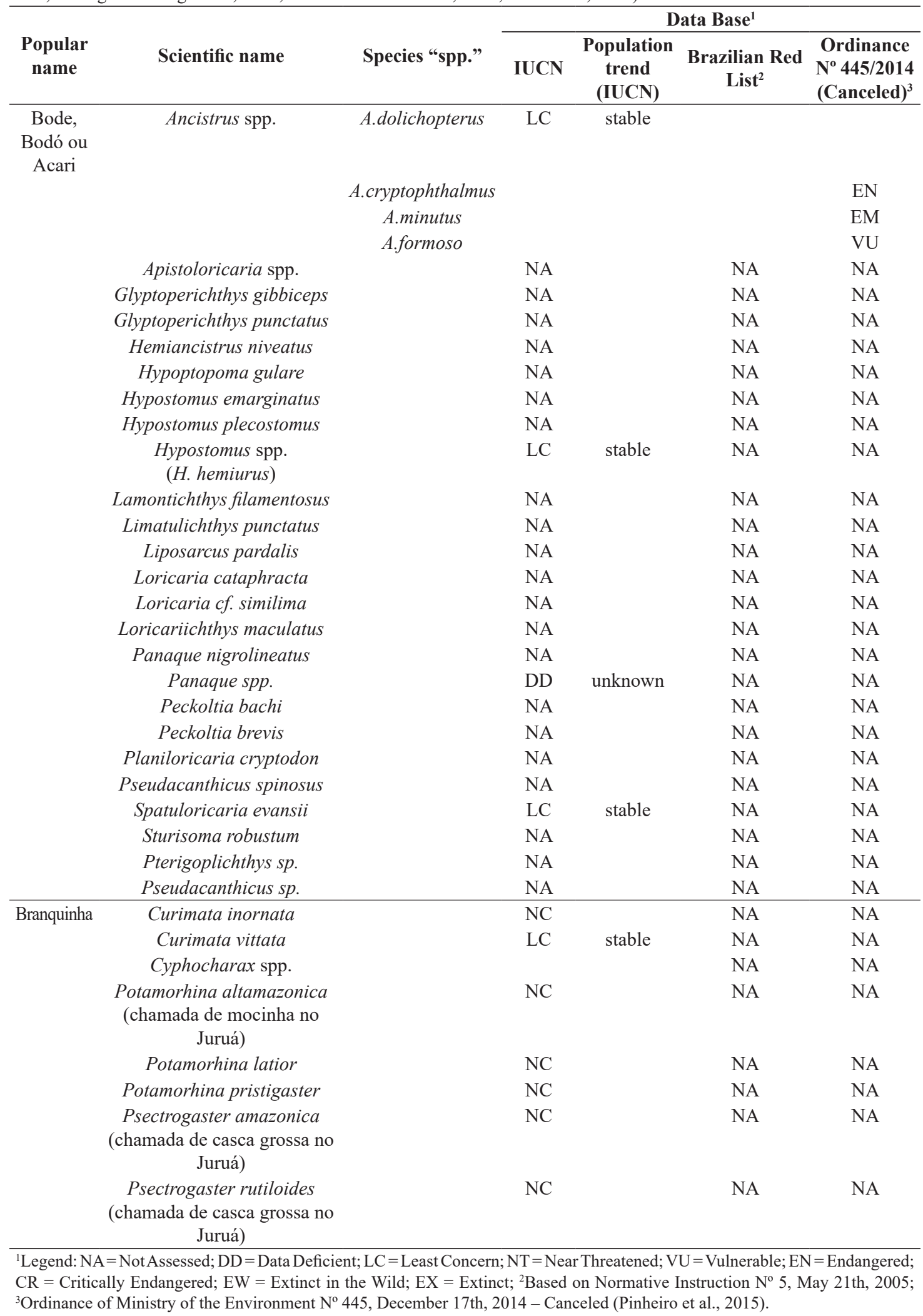


Table 3. Continued...

\begin{tabular}{|c|c|c|c|c|c|c|}
\hline \multirow[b]{2}{*}{$\begin{array}{l}\text { Popular } \\
\text { name }\end{array}$} & \multirow[b]{2}{*}{ Scientific name } & \multirow[b]{2}{*}{ Species "spp." } & \multicolumn{4}{|c|}{ Data Base $^{1}$} \\
\hline & & & IUCN & $\begin{array}{c}\text { Population } \\
\text { trend } \\
\text { (IUCN) }\end{array}$ & $\begin{array}{l}\text { Brazilian Red } \\
\text { List }^{2}\end{array}$ & $\begin{array}{c}\text { Ordinance } \\
N^{0} 445 / 2014 \\
\text { (Canceled) }^{3}\end{array}$ \\
\hline & Psectrogasteressequibensis & & $\mathrm{NC}$ & & NA & NA \\
\hline & Curimata amazonica & & $\mathrm{NC}$ & & NA & NA \\
\hline & $\begin{array}{l}\text { Curimatella immaculata } \\
\text { (saburu) }\end{array}$ & & $\mathrm{NC}$ & & NA & NA \\
\hline & $\begin{array}{l}\text { Steindachnerina spp. (S. } \\
\text { amazonica), (saburu) }\end{array}$ & & $\mathrm{LC}$ & stable & NA & NA \\
\hline Curimatá & Prochilodus nigricans & & NA & & NA & NA \\
\hline \multirow[t]{3}{*}{ Jaraqui } & Semaprochilodus brama & & NA & & NA & NA \\
\hline & Semaprochilodus insignis & & NA & & $\begin{array}{l}\text { Overexploited } \\
\text { or Threatened } \\
\text { overexploitation }\end{array}$ & NA \\
\hline & Semaprochilodus taeniurus & & $\mathrm{LC}$ & stable & $\begin{array}{l}\text { Overexploited } \\
\text { or Threatened } \\
\text { overexploitation }\end{array}$ & NA \\
\hline \multirow[t]{18}{*}{ Mandi } & Cheirocerus goeldii & & NA & & NA & NA \\
\hline & Megalonema platycephalum & & NA & & NA & NA \\
\hline & Pimelodella cristata & & $\mathrm{LC}$ & stable & NA & NA \\
\hline & Pimelodella gracilis & & NA & & NA & NA \\
\hline & Pimelodina flavipinnis & & NA & & NA & NA \\
\hline & Pimelodus aff. altissimus & & NA & & NA & NA \\
\hline & $\begin{array}{c}\text { Pimelodus blochii } \\
\text { (mandi cabeça de ferro) }\end{array}$ & & NA & & NA & NA \\
\hline & Pimelodus spp. & & & & & \\
\hline & & P.halisodous & & & & VU \\
\hline & & P. joannis & & & & VU \\
\hline & & P. stewartii & & & & VU \\
\hline & Hassar wilderi & & NA & & NA & NA \\
\hline & Megalodoras irwini & & NA & & NA & NA \\
\hline & Trachydoras trachyparia & & NA & & NA & NA \\
\hline & Centromochlus heckelli & & NA & & NA & NA \\
\hline & $\begin{array}{l}\text { Centromochlus sp. } \\
\text { (C. reticulatus) }\end{array}$ & & $\mathrm{LC}$ & stable & NA & NA \\
\hline & Luciopimelodus sp. & & NA & & NA & NA \\
\hline & Cheirocerus eques & & NA & & NA & NA \\
\hline \multirow[t]{9}{*}{ Pacu } & Metynnis hypsauchen & & NA & & NA & NA \\
\hline & Metynnis lippincottianus & & NA & & NA & NA \\
\hline & Myleus rubripinnis & & NA & & NA & NA \\
\hline & Myleus schomburgkii & & NA & & NA & NA \\
\hline & Myleus spp. & & NA & & NA & NA \\
\hline & Myleus torquatus & & NA & & NA & NA \\
\hline & Mylossoma aureum & & NA & & NA & NA \\
\hline & $\begin{array}{l}\text { Mylossoma duriventre } \\
\text { (pacu manteiga) }\end{array}$ & & NA & & NA & NA \\
\hline & Myleus pacu & & NA & & NA & NA \\
\hline \multirow[t]{3}{*}{ Piau } & Abramites hypselonotus & & NA & & NA & NA \\
\hline & Anostomoides laticeps & & NA & & NA & NA \\
\hline & Laemolyta petite & & NA & & NA & NA \\
\hline
\end{tabular}

${ }^{1}$ Legend: NA = NotAssessed; DD = Data Deficient LC = Least Concern; NT = Near Threatened; VU = Vulnerable; EN = Endangered; $\mathrm{CR}=$ Critically Endangered; EW $=$ Extinct in the Wild; EX $=$ Extinct; ${ }^{2}$ Based on Normative Instruction $N^{\circ}$ 5, May 21th, 2005; ${ }^{3}$ Ordinance of Ministry of the Environment $N^{\circ} 445$, December 17th, 2014 - Canceled (Pinheiro et al., 2015). 
Table 3. Continued...

\begin{tabular}{|c|c|c|c|c|c|c|}
\hline \multirow[b]{2}{*}{$\begin{array}{l}\text { Popular } \\
\text { name }\end{array}$} & \multirow[b]{2}{*}{ Scientific name } & \multirow[b]{2}{*}{ Species "spp." } & \multicolumn{4}{|c|}{ Data Base $^{1}$} \\
\hline & & & IUCN & $\begin{array}{c}\text { Population } \\
\text { trend } \\
\text { (IUCN) }\end{array}$ & $\begin{array}{l}\text { Brazilian Red } \\
\text { List }^{2}\end{array}$ & $\begin{array}{c}\text { Ordinance } \\
\mathrm{N}^{0} 445 / 2014 \\
{\text { (Canceled })^{3}}\end{array}$ \\
\hline & Laemolyta spp. & & NA & & NA & NA \\
\hline & Laemolyta varia & & NA & & NA & NA \\
\hline & Leporinus affinis & & NA & & NA & NA \\
\hline & Leporinus agassizii & & NA & & NA & NA \\
\hline & Leporinus falcipinnis & & NA & & NA & NA \\
\hline & Leporinus fasciatus & & NA & & NA & NA \\
\hline & $\begin{array}{l}\text { Leporinus friderici } \\
\text { (piau cabeça-gorda) }\end{array}$ & & NA & & NA & NA \\
\hline & Leporinus spp. (L. granti) & & $\mathrm{LC}$ & stable & NA & NA \\
\hline & Leporinus trifasciatus & & NA & & NA & NA \\
\hline & Schizodon fasciatus & & NA & & NA & NA \\
\hline & $\begin{array}{l}\text { Schizodon vittatus } \\
\text { (piau vara) }\end{array}$ & & NA & & NA & NA \\
\hline \multirow[t]{7}{*}{ Piranha } & Pristobrycon striolatus & & NA & & NA & NA \\
\hline & $\begin{array}{l}\text { Pygocentrus nattereri } \\
\text { (piranha vermelha) }\end{array}$ & & NA & & NA & NA \\
\hline & Serrasalmus eigenmanni & & NA & & NA & NA \\
\hline & Serrasalmus gouldingi & & NA & & NA & NA \\
\hline & Serrasalmus marginatus & & NA & & NA & NA \\
\hline & $\begin{array}{l}\text { Serrasalmus rhombeus } \\
\quad \text { (piranha preta) }\end{array}$ & & NA & & NA & NA \\
\hline & $\begin{array}{l}\text { Serrasalmus spilopleura } \\
\text { (piranha preta) }\end{array}$ & & NA & & NA & NA \\
\hline Tucunaré & $\begin{array}{l}\text { Cichla temensis } \\
\text { (tucunaré comum, tucunaré açu) }\end{array}$ & & NA & & NA & NA \\
\hline & $\begin{array}{l}\text { Cichla ocellaris } \\
\text { (tucunaré pitanga) }\end{array}$ & & NA & & NA & NA \\
\hline & Cichla kelberi & & NA & & NA & NA \\
\hline & Cichla monoculus & & NA & & NA & NA \\
\hline & Cichla orinocensis & & NA & & NA & NA \\
\hline & Cichla pinima & & NA & & NA & NA \\
\hline
\end{tabular}

${ }^{1}$ Legend: NA = NotAssessed; DD = Data Deficient LC = Least Concern; $N T=$ Near Threatened; $V U=$ Vulnerable; EN = Endangered; $\mathrm{CR}=$ Critically Endangered; $\mathrm{EW}=$ Extinct in the Wild; $\mathrm{EX}=$ Extinct; ${ }^{2}$ Based on Normative Instruction $\mathrm{N}^{\circ}$ 5, May 21th, 2005;

${ }^{3}$ Ordinance of Ministry of the Environment N ${ }^{\circ} 445$, December 17th, 2014 - Canceled (Pinheiro et al., 2015).

systems (Defeo and Castilla, 2005; Gelcich et al., 2008; Lopes et al., 2011; Silvano et al., 2014). A first step would be to reveal those fish most important to sustain livelihoods and food security; to identify those most threatened; and then devise policies to maintain these fish species before they are gone. For several years, Brazilian researchers have been stressing the impacts that hydroelectric power plants have on fish. Most important are those that cause a sharp decrease in the species richness (for example, in Tucuruí Reservoir about $50 \%$ of the fish species have been lost), and those that have a drastic impact on migratory species (Petrere Junior, 1989, 1996; Barthem et al., 1991; Kahn et al., 2014). More recently, a study has shown that the environmental impact assessments are very limited in Brazil, with poor methodologies and imprecise requirements, preventing the identification of impacts and possible mitigating actions (one example approached the Belo Monte Dam) (Ritter et al., 2017). However, more than 10 years ago researchers have claimed on the impacts hydroelectric could cause (Tundisi, 2007). Giving the scale and timing of change happening in Amazonian rivers, action is needed now to ensure that our rivers can continue to feed riverine people.

\section{Conclusions}

Our concluding remarks summarize the evidence and observations on the association between biodiversity loss and increased food insecurity, as follows: 
1 Hydropower development in the Amazon could negatively affect river fisheries.

2. While the national diet in Brazil has only a small portion of freshwater fish $(1.5 \%)$, the protein diet of the riverine Amazonian Caboclos small-scale fishers (based on research in communities of 773,000 estimated people in total/IBGE) is substantially dependant on riverine fish for protein (around 70\% of protein in their diet).

3. The Caboclos target particular species when fishing.

4. The majority (78\%) of the targeted fish species are either regarded as 'not known' or threatened. This is a very important. consideration, since it is likely that some species could to disappear before we will have appropriate knowledge for their conservation.

5. The targeted fish species might be vulnerable as a result of many individual and combined impacts, such as overfishing and multiple hydropower dam development.

6. In this review we reinforce suggestions that hydropower development (along with other development pressures) in the Amazon may threaten the food security of the Caboclos in Brazil. The data of the main fish species consumed by the Caboclos show that impact from dams could potentially affect the main species consumed and therefore the food security of riverine Caboclos.

\section{Acknowledgements}

We are very grateful to FAPESP grants (14/24994-8 and in the Appendix) as well as to the collaborative project (authors AB, DD, JP): "Managing links between hydropower development, fish and foods" funded by ANU's Brazilian Regional Reference Group Collaboration Scheme (Australia). We thank CNPq for productivity scholarships to A.B., N.H. and R.A.M.S.

\section{References}

ABELL., THIEME, M.L., REVENGA, C., BRYER, M., KOTTELAT, M., BOGUTSKAYA, N., COAD, B., MANDRAK, N., BALDERAS, S.C., BUSSING, W., STIASSNY, M.L.J., SKELTON, P., AlLEN, G.R., UNMACK, P., NASEKA, A., NG, R., SINDORF, N., ROBERTSON, J., ARMIJO, E., HIGGINS, J.V., HEIBEL, T.J., WIKRAMANAYAKE, E., OLSON, D., LÓPEZ, H.L., REIS, R.E., LUNDBERG, J.G., PÉREZ, M.H.S. and PETRY, P., 2008. Freshwater ecoregions of the world: a new map of biogeographic units for freshwater biodiversity conservation. Bioscience, vol. 58, no. 5, pp. 403-414. http://dx.doi.org/10.1641/B580507.

AINSWORTH, C.H., PITCHER, T.J. and ROTINSULU, C., 2008. Evidence of fishery depletions and shifting cognitive baselines in Eastern Indonesia. Biological Conservation, vol. 141, no. 3, pp. 848-859. http://dx.doi.org/10.1016/j.biocon.2008.01.006.
ANDREW, N.L., BÉNÉ, C., HALL, S.J., ALLISON, E.H., HECK, S. and RATNER, B.D., 2007. Diagnosis and management of small-scale fisheries in developing countries. Fish and Fisheries, vol. 8, no. 3, pp. 227-240. http://dx.doi.org/10.1111/j.14672679.2007.00252.x.

BARTHEM, R.B., RIBEIRO, M.C.L.B. and PETRERE JUNIOR, M., 1991. Life strategies of some long-distance migratory catfish in relation to hydroelectric dams in the Amazon Basin. Biological Conservation, vol. 55, no. 3, pp. 339-345. http://dx.doi. org/10.1016/0006-3207(91)90037-A.

BARTLEY, D.M., DE GRAAF, G.J., VALBO-JØRGENSEN, J. and MARMULLA, G., 2015. Inland capture fisheries: status and data issues. Fisheries Management and Ecology, vol. 22, no. 1, pp. 71-77. http://dx.doi.org/10.1111/fme.12104.

BATISTA, V.S., INHAMUNS, A.J., FREITAS, C.D.C. and FREIRE-BRASIL, D., 1998. Characterization of the fishery in river communities in the low-solimões/high-amazon region. Fisheries Management and Ecology, vol. 5, no. 5, pp. 419-435. http://dx.doi.org/10.1046/j.1365-2400.1998.550419.x.

BEGOSSI, A. and BRAGA, S., 1992. Food taboos and folk medicine among fishermen from the Tocantins River (Brazil). Amazoniana, vol. 12, no. 1, pp. 101-118.

BEGOSSI, A. and FIGUEIREDO, L., 1995. Ethnoichthyology of southern coastal fishermen: cases from Búzios Island and Sepetiba Bay (Brazil). Bulletin of Marine Science, vol. 56, no. 2, pp. 710-717.

BEGOSSI, A. and GARAVELLO, J.C., 1990. Notes on the ethnoicthyology of fishermen from the Tocantins River (Brazil). Acta Amazonica, vol. 20, no. 20, pp. 341-351. http://dx.doi. org/10.1590/1809-43921990201351.

BEGOSSI, A., 2014. Ecological, cultural, and economic approaches to managing artisanal fisheries. Environment, Development and Sustainability, vol. 16, no. 1, pp. 5-34. http://dx.doi.org/10.1007/ s10668-013-9471-z.

BEGOSSI, A., HANAZAKI, N. and PERONI, N., 2000. Knowledge and use of biodiversity in Brazilian hot spots. Environment, Development and Sustainability, vol. 2, no. 3-4, pp. 177-193. http://dx.doi.org/10.1023/A:1011409923520.

BEGOSSI, A., HANAZAKI, N. and RAMOS, R.M., 2004. Food chain and the reasons for fish food taboos among Amazonian and Atlantic Forest fishers (Brazil). Ecological Applications, vol. 14, no. 5, pp. 1334-1343. http://dx.doi.org/10.1890/03-5072.

BEGOSSI, A., LOPES, P. and SILVANO, R., 2012a. CoManagement of reef fisheries of the snapper-grouper complex in a human ecological context in Brazil. In: G.H. Kruse, H.I. Browman, K.L. Cochrane, D. Evans, G.S. Jamieson, P.A. Livingston, D. Woodby, and C.I. Zhang, eds. Global progress in ecosystem-based fisheries management. Fairbanks: Alaska Sea Grant, University of Alaska Fairbanks. http://dx.doi.org/10.4027/gpebfm.2012.018.

BEGOSSI, A., MAY, P.H., LOPES, P.F., OLIVEIRA, L.E., VINHA, V. and SILVANO, R.A.M., 2011. Compensation for environmental services from artisanal fisheries in SE Brazil: Policy and technical strategies. Ecological Economics, vol. 1, pp. 25-32. http://dx.doi.org/10.1016/j.ecolecon.2011.09.008.

BEGOSSI, A., SALIVONCHYK, S.V., HANAZAKI, N., MARTINS, I.V. and BUELONI, F., 2012b. Fishers (Paraty, RJ) and fish manipulation time: a variable associated to the choice for consumption and sale. Brazilian Journal of Biology $=$ Revista Brasileira de Biologia, vol. 72, no. 4, pp. 973-975. http://dx.doi. org/10.1590/S1519-69842012000500030. PMid:23295533. 
BEGOSSI, A., SALYVONCHYK, S.V., NORA, V., LOPES, P.F. and SILVANO, R.A.M., 2012c. The Paraty artisanal fishery (southeastern Brazilian coast): ethnoecology and management of a social-ecological system (SES). Journal of Ethnobiology and Ethnomedicine, vol. 8, no. 1, pp. 22. http://dx.doi.org/10.1186/17464269-8-22. PMid:22738073.

BEGOSSI, A., SILVANO, R.A.M., AMARAL, B.D. and OYAKAWA, O.T., 1999. Uses of fish and game by inhabitants of an extractive reserve (Upper Juruá, Acre, Brazil). Environment, Development and Sustainability, vol. 1, no. 1, pp. 73-93. http:// dx.doi.org/10.1023/A:1010075315060.

BEGOSSI, A., SALIVONCHYK, S., HALLWASS, G., HANAZAKI, N., LOPES, P.F.M. AND SILVANO, R.A.M., 2017. Threatened fish and fishers along the Brazilian Atlantic Forest Coast. Ambio, vol. 46, no. 8, pp. 907-914. https://doi.org/10.1007/s13280-0170931-9. PMid:28710567

BENCHIMOL, M. and PERES, C.A., 2015. Widespread forest vertebrate extinctions induced by a mega hydroelectric dam in lowland Amazonia. PLoS One, vol. 10, no. 7, pp. e0129818. http://dx.doi.org/10.1371/journal.pone.0129818. PMid:26132139.

BENE, C., 2006. Small-scale fisheries: assessing their contribution to rural livelihoods in developing countries. Rome: FAO. FAO Fisheries Circular, no. 2008.

BÉNÉ, C., ARTHUR, R., NORBURY, H., ALLISON, E.H., BEVERIDGE, M., BUSH, S., CAMPLING, L., LESCHEN, W., LITTLE, D., SQUIRES, D., THILSTED, S.H., TROELL, M. and WILLIAMS, M., 2016. Contribution to fisheries and Aquaculture to food security and poverty reduction: assessing the current evidence. World Development, vol. 79, pp. 177-196. http://dx.doi.org/10.1016/j.worlddev.2015.11.007.

BÉNÉ, C., BARANGE, M., SUBASINGHE, R., PINSTRUPANDERSEN, P., MERINO, G., HEMRE, G. and WILLIAMS, M., 2015. Feeding 9 billion by 2050 - Putting fish back on the menu. Food Security, vol. 7, no. 2, pp. 261-274. http://dx.doi. org/10.1007/s12571-015-0427-z.

BOISCHIO, A.A.P. and HENSHEL, P., 2000. Fish consumption, fish lore and mercury pollution: risk communication for the Madeira River People. Environmental Research Section A, vol. 84, no. 2, pp. 108-126. http://dx.doi.org/10.1006/enrs.2000.4035. PMid:11068924.

CARNEIRO, F. and SOUZA, O.B., 2009. Atlas de pressões e ameaças às terras indígenas na Amazônia Brasileira. São Paulo: Instituto Socioambiental. $48 \mathrm{p}$.

CASTELlO, L., MCGRATH, D.G., HESS, L.L., COE, M.T., LEFEBVRE, P.A., PETRY, P., MACEDO, M.N., RENÓ, V.F. and ARANTES, C.C., 2013. The vulnerability of Amazon freshwater ecosystems. Conservation Letters, vol. 6, no. 4, pp. 217-229. http://dx.doi.org/10.1111/conl.12008.

CERDEIRA, R.G.P., RUFFINO, M.L. and ISAAC, V.J., 1997. Consumo de pescado e outros alimentos pela população ribeirinha do Lago Grande de Monte Alegre, PA - Brasil. Acta Amazonica, vol. 27, no. 3, pp. 213-227. http://dx.doi.org/10.1590/180943921997273228

DE GRAAF, G.J., GRAINGER, R.J.R., WESTLUND, L., WILLMANN, R., MILLS, D., KELlEHER, K. and KORANTENG, K., 2011. The status of routine fishery data collection in Southeast Asia, central America, the South Pacific, and West Africa, with special reference to small-scale fisheries. ICES Journal of Marine Science, vol. 68, no. 8, pp. 1743-1750. http://dx.doi.org/10.1093/icesjms/fsr054.
DEFEO, O. and CASTILLA, J.C., 2005. More than one bag for the world fishery crisis and keys for co-management successes in selected artisanal Latin American shellfisheries. Reviews in Fish Biology and Fisheries, vol. 15, no. 3, pp. 265-283. http://dx.doi. org/10.1007/s11160-005-4865-0.

DUGAN, P.J., BARAN, E., THARME, R., PREIN, M., AHMED, R., AMERASINGHE, P., BUENO, P., BROWN, C., DEY, M., JAYASINGHE, G., NIASSE, M., NIELAND, A., SMAKHTIN, V., TINH, N., VISWANATHAN, K. and WELCOMME, R., 2002. The contribution of aquatic ecosystems and fisheries to food security and livelihoods: a research agenda. In: CGIAR. Challenge Program on Water and Food: background papers to the full proposal. Colombo: CGIAR Challenge Program on Water and Food. pp. 85-113. Background Paper, no. 3.

FEARNSIDE, P.M., 1999. Social impacts of Brazil's Tucuruí Dam. Environmental Management, vol. 24, no. 4, pp. 483-495. http://dx.doi.org/10.1007/s002679900248. PMid:10501861.

FEARNSIDE, P.M., 2004. Greenhouse gas emissions from hydroelectric dams: controversies provide a springboard for rethinking a supposedly 'clean' energy source. an editorial comment. Climatic Change, vol. 66, no. 1/2, pp. 1-18. http:// dx.doi.org/10.1023/B:CLIM.0000043174.02841.23.

FEARNSIDE, P.M., 2015. Highway construction as a force in destruction of the Amazon forest. In: R. VAN DER REE, D.J. SMITH and C. GRILO, eds. Handbook of road ecology. Oxford: John Wiley \& Sons Publishers. pp. 414-424. http://dx.doi. org/10.1002/9781118568170.ch51.

FEARNSIDE, P.M., 2016. Tropical dams: to build or not to build? Science, vol. 351, no. 6272, pp. 456-457. http://dx.doi. org/10.1126/science.351.6272.456-b. PMid:26823417.

FISHERIES AND FOOD INSTITUTE [online], 2015 [viewed 10 July 2015]. Available from: www.fisheriesandfood.com

FOOD AND AGRICULTURE ORGANIZATION - FAO, 2011. World by continent - food balance sheet of fish and fishery products in live weight and fish contribution to protein supply. Rome: Food and Agriculture Organisation of the United Nations.

FOOD AND AGRICULTURE ORGANIZATION - FAO, 2013a. Fish, crustaceans, molluscs, etc.: world capture production. Rome: Food and Agriculture Organization of the United Nations.

FOOD AND AGRICULTURE ORGANIZATION - FAO, $2013 \mathrm{~b}$. World fisheries production, by capture and aquaculture, by country. Rome: Food and Agriculture Organisation of the United Nations.

GARCIA, A., TELLO, S., VARGAS, G. and DUPONCHELLE, F., 2009. Patterns of Commercial Fish Landings in the Loreto Region (Peruvian Amazon) Between 1984 and 2006. Fish Physiology and Biochemistry, vol. 35, no. 1, pp. 53-67. http://dx.doi.org/10.1007/ s10695-008-9212-7. PMid:19189235.

GEHRKE, P.C., GILLIGAN, D.M. and BARWICK, M., 2002. Changes in fish communities of the Shoalhaven River 20 years after construction of Tallowa Dam, Australia. River Research and Applications, vol. 18, no. 3, pp. 265-286. http://dx.doi. org/10.1002/rra.669.

GELCICH, S., KAISER, M.J., CASTILLA, J.C. and EDWARDSJONES, G., 2008. Engagement in co-management of marine benthic resources influences environmental perceptions of artisanal fishers. Environmental Conservation, vol. 35, no. 1, pp. 36-45. http://dx.doi.org/10.1017/S0376892908004475.

HALLWASS, G. and SILVANO, R.A.M., 2016. Patterns of selectiveness in the Amazonian freshwater fisheries: implications for management. Journal of Environmental Planning and 
Management, vol. 59, no. 9, pp. 1537-1559. http://dx.doi.org/1 0.1080/09640568.2015.1081587.

HALLWASS, G., LOPES, P.F., JURAS, A.A. and SILVANO, R.A.M., 2011. Fishing effort and catch composition of urban market and rural villages in Brazilian Amazon. Environmental Management, vol. 47, no. 2, pp. 188-200. http://dx.doi.org/10.1007/ s00267-010-9584-1. PMid:21153639.

HALLWASS, G., LOPES, P.F., JURAS, A.A. and SILVANO, R.A.M., 2013. Fishers' knowledge identifies environmental changes and fish abundance trends in impounded tropical rivers. Ecological Applications, vol. 23, no. 2, pp. 392-407. http://dx.doi. org/10.1890/12-0429.1. PMid:23634590.

INTERNATIONAL UNION FOR CONSERVATION OF NATURE - IUCN, 2014 [viewed 10 July 2015]. IUCN red list [online]. Cambridge: IUCN UK Office. Available from: http:// www.iucnredlist.org/

ISAAC, V.J. and ALMEIDA, M.C., 2011. El consumo de pescado en la amazonía brasileña. Rome: Organización de las Naciones Unidas para la Agricultura y la Alimentación. No. CIDAB-SH1-F62c-13.

ISAAC, V.J., ALMEIDA, M.C., GIARRIZZO, T., DEUS, C.P., VALE, R., KLEIN, G. and BEGOSSI, A., 2015. Food consumption as an indicator of the conservation of natural resources in riverine communities of the Brazilian Amazon. Anais da Academia Brasileira de Ciências, vol. 87, no. 4, pp. 2229-2242. http:// dx.doi.org/10.1590/0001-3765201520140250. PMid:26628023.

ISAAC, V.J., SILVA, C.O. and RUFFINO, M.L., 2008. The artisanal fishery fleet of the lower Amazon. Fisheries Management and Ecology, vol. 15, no. 3, pp. 179-187. http:// dx.doi.org/10.1111/j.1365-2400.2008.00599.x.

JACKSON, J.B.C., KIRBY, M.X., BERGER, W.H., BJORNDAL, K.A., BOTSFORD, L.W., BOURQUE, B.J., BRADBURY, R.H., COOKE, R., ERLANDSON, J., ESTES, J.A., HUGHES, T.P., KIDWELL, S., LANGE, C.B., LENIHAN, H.S., PANDOLFI, J.M., PETERSON, C.H., STENECK, R.S., TEGNER, M.J. and WARNER, R.R., 2001. Historical overfishing and the recent collapse of coastal ecosystems. Science, vol. 293, no. 5530, pp. 629-637. http://dx.doi.org/10.1126/science.1059199. PMid:11474098.

JUNK, W.J., SOARES, M.G.M. and BAYLEY, P.B., 2007. Freshwater fishes of the Amazon River basin: their biodiversity, fisheries, and habitats. Aquatic Ecosystem Health \& Management, vol. 10, no. 2, pp. 153-173. http://dx.doi.org/10.1080/14634980701351023.

KAHN, J.R., FREITAS, C.E. and PETRERE, M., 2014. False shades of green: the case of Brazilian Amazonian hydropower. Energies, vol. 7, no. 9, pp. 6063-6082. http://dx.doi.org/10.3390/ en7096063.

LEITE, M.C. and GASALLA, M.A., 2013. A method for assessing fishers' ecological knowledge as a practical tool for ecosystem-based fisheries management: Seeking consensus in Southeastern Brazil. Fisheries Research, vol. 145, pp. 43-53. http://dx.doi.org/10.1016/j.fishres.2013.02.013.

LOPES, P.F., PACHECO, S., CLAUZET, M., SILVANO, R.A.M. and BEGOSSI, A., 2015. Fisheries, tourism, and marine protected areas: conflicting or synergistic interactions? Ecosystem Services, vol. 16, pp. 333-340. http://dx.doi.org/10.1016/j.ecoser.2014.12.003.

LOPES, P.F., ROSA, E.M., SALYVONCHYK, S.V., NORA, V. and BEGOSSI, A., 2013. Suggestions for fixing top-down coastal fisheries management through participatory approaches. Marine Policy, vol. 40, pp. 100-110. http://dx.doi.org/10.1016/j. marpol.2012.12.033.
LOPES, P.F.M., SILVANO, R.A.M. and BEGOSSI, A., 2011. Extractive and Sustainable Development Reserves in Brazil: resilient alternatives to fisheries? Journal of Environmental Planning and Management, vol. 54, no. 4, pp. 421-443. http:// dx.doi.org/10.1080/09640568.2010.508687.

MCCLANAHAN, T., ALLISON, E.H. and CINNER, J.E., 2015. Managing fisheries for human and food security. Fish and Fisheries, vol. 16, no. 1, pp. 78-103. http://dx.doi.org/10.1111/faf.12045.

MÉRONA, B., JURAS, A. F., SANTOS, G.M., CINTRA, I.H.A., 2010. Os peixes e a pesca no baixo Rio Tocantins: vinte anos depois da UHE Tucuruí. Brasília: Centrais Elétricas do Nort e do Brasil S.A; Eletrobras-Eletronorte; Ministério de Minas e Energia.

MÉRONA, B., SANTOS, G.M. and ALMEIDA, R.G., 2001. Short term effects of Tucuruí Dam (Amazonia, Brazil) on the trophic organization of fish communities. Environmental Biology of Fishes, vol. 60, no. 4, pp. 375-392. http://dx.doi. org/10.1023/A:1011033025706.

MOLLE, F., MOLLINGA, P.P. and WESTER, P., 2010. Hydraulic bureaucracies: flows of water, flows of power. Water Alternatives, vol. 2, pp. 328-349.

MORAN, E.F., 1996. The adaptive system of the Amazonian caboclo. Man in the Amazon. 1974; 136: 139-159. Regulated Rivers: Research and Management, vol. 12, pp. 81-98.

MYERS, R.A. and WORM, B., 2003. Rapid worldwide depletion of predatory fish communities. Nature, vol. 423, no. 6937, pp. 280-283. http://dx.doi.org/10.1038/nature01610. PMid:12748640.

NUGENT, S., 1993. Amazonian caboclo society: an essay on invisibility and peasant economy. Providence, Rhode Island: Berg Publishers Ltd.

ORR, S., PITTOCK, J., CHAPAGAIN, A. and DUMARESQ, D., 2012. Dams on the Mekong river: lost fish protein and the implications for land and water resources. Global Environmental Change, vol. 22, no. 4, pp. 925-932. http://dx.doi.org/10.1016/j. gloenvcha.2012.06.002.

PAULY, D., 1995. Anecdotes and the shifting baseline syndrome in fisheries. Trends in Ecology \& Evolution, vol. 10, no. 10, pp. 430. http://dx.doi.org/10.1016/S0169-5347(00)89171-5. PMid:21237093.

PAULY, D., 2006. Major trends in small-scale marine fisheries, with emphasis on developing countries, and some implications for the social sciences. Maritime Studies, vol. 4, no. 2, pp. 7-22.

PAULY, D., CHRISTENSEN, V., DALSGAARD, J., FROESE, R. and TORRES JUNIOR, F., 1998. Fishing down marine food webs. Science, vol. 279, no. 5352, pp. 860-863. http://dx.doi. org/10.1126/science.279.5352.860. PMid:9452385.

PAULY, D., CHRISTENSEN, V., GUÉNETTE, S., PITCHER, T.J., SUMAILA, U.R., WALTERS, C.J., WATSON, R. and ZELLER, D., 2002. Towards sustainability in world fisheries. Nature, vol. 418, no. 6898, pp. 689-695. http://dx.doi.org/10.1038/ nature01017. PMid:12167876.

PETESSE, M.L. and PETRERE JUNIOR, M., 2012. As barragens e os peixes: o impacto das grandes hidrelétricas nas espécies dos rios represados. Ciência Hoje, vol. 49, pp. 30-35.

PETRERE JUNIOR, M., 1989. River fisheries in Brazil: a review. Regulated Rivers: Research and Management, vol. 4, no. 1, pp. 1-6. http://dx.doi.org/10.1002/rrr.3450040102.

PETRERE JUNIOR, M., 1996. Fisheries in large tropical reservoirs in South America. Lakes and Reservoirs: Research 
and Management, vol. 2, no. 1-2, pp. 111-133. http://dx.doi. org/10.1111/j.1440-1770.1996.tb00054.x.

PINHEIRO, H.T., DARIO, F., GERHARDINGER, L.C., MELO, M.R., MOURA, R.L., REIS, R.E., VIEIRA, F., ZUANON, J. and ROCHA, L.A., 2015. Brazilian aquatic biodiversity in peril. Science, vol. 350, no. 6264, pp. 1043-1044. http://dx.doi. org/10.1126/science.350.6264.1043-a. PMid:26612943.

PINNEGAR, J.K. and ENGELHARD, G.H., 2007. The 'shifting baseline' phenomenon: a global perspective. Reviews in Fish Biology and Fisheries, vol. 18, no. 1, pp. 1-16. http://dx.doi. org/10.1007/s11160-007-9058-6.

PONTON, D. and VAUCHEL, P., 1998. Immediate downstream effects of the Petit-Saut Dam on Young neotropical fish in a large tributary of the Sinnamary River (French Guiana, South America). Regulated Rivers: Research and Management, vol. 14, no. 3, pp. 227-243. http://dx.doi.org/10.1002/(SICI)10991646(199805/06)14:3<227::AID-RRR490>3.0.CO;2-6.

PRESTES-CARNEIRO, G., BÉAREZ, P., BAILON, S., PYDANIEL, A.R. and NEVES, E.G., 2015. Subsistence fishery at Hatahara (750-1230 CE), a pre-Columbian central Amazonian village. Journal of Archaeological Science: Reports, vol. 8, pp. 454-462. https://doi.org/10.1016/j.jasrep.2015.10.033.

RITTER, C.D., MCCRATE, G., NILSSON, R.K., FEARNSIDE, P.M., PALME, U. and ANTONELLI, A., 2017. Environmental impact assessment in Brazilian Amazonia: challenges and prospects to assess biodiversity. Biological Conservation, vol. 206, pp. 161-168. http://dx.doi.org/10.1016/j.biocon.2016.12.031.

SARTI, F.M., ADAMS, C., MORSELLO, C., VAN VLIET, N., SCHOR, T., YAGÜE, B., TELLEZ, L., QUICENO-MESA, M.P. and CRUZ, D., 2015. Beyond protein intake: bushmeat as source of micronutrients in the Amazon. Ecology and Society, vol. 20, no. 4, pp. 22. http://dx.doi.org/10.5751/ES-07934-200422.

SETHI, S.A., BRANCH, T.A. and WATSON, R., 2010. Global fishery development patterns are driven by profit but not trophic level. Proceedings of the National Academy of Sciences of the United States of America, vol. 107, no. 27, pp. 12163-12167. http://dx.doi.org/10.1073/pnas.1003236107. PMid:20566867.

SHRIMPTON, R. and GIUGLIANO, R., 1979. Consumo de alimentos e alguns nutrients em Manaus, Amazonas. 197374. Acta Amazonica, vol. 9, no. 1, pp. 117-141. http://dx.doi. org/10.1590/1809-43921979091117

SILVA, A.L. and BEGOSSI, A., 2009. Biodiversity, food consumption and ecological niche dimension: a study case of the riverine populations from the Rio Negro, Amazonia, Brazil. Environment, Development and Sustainability, vol. 11, no. 3, pp. 489-507. http://dx.doi.org/10.1007/s10668-007-9126-z.

SILVANO, R.A.M. and BEGOSSI, A., 2012. Fishermen's local ecological knowledge on Southeastern Brazilian coastal fishes: contributions to research, conservation, and management. Neotropical Ichthyology, vol. 10, no. 1, pp. 133-147. http://dx.doi. org/10.1590/S1679-62252012000100013.

SILVANO, R.A.M., HALLWASS, G., LOPES, P.F., RIBEIRO, A.R., LIMA, R.P., HASENACK, H., JURAS, A.A. and BEGOSSI, A., 2014. Co-management and spatial features contribute to secure fish abundance and fishing yields in tropical floodplain lakes. Ecosystems (New York, N.Y.), vol. 17, no. 2, pp. 271-285. http://dx.doi.org/10.1007/s10021-013-9722-8.

SILVANO, R.A.M., MACCORD, P.F., LIMA, R.V. and BEGOSSI, A., 2006. When does this fish spawn? Fishermen's local knowledge of migration and reproduction of Brazilian coastal fishes. Environmental Biology of Fishes, vol. 76, no. 2-4, pp. 371-386. http://dx.doi.org/10.1007/s10641-006-9043-2.
SILVANO, R.A.M., SILVA, A.L., CERONI, M. and BEGOSSI, A., 2008. Contributions of ethnobiology to the conservation of tropical rivers and streams. Aquatic Conservation, vol. 18, no. 3, pp. 241-260. http://dx.doi.org/10.1002/aqc.825.

SMITH, N.J.H., 1985. The impact of cultural and ecological change on Amazonian fisheries. Biological Conservation, vol. 32, no. 4, pp. 355-373. http://dx.doi.org/10.1016/0006-3207(85)90023-0.

SOLARTE, L.G., CASTAÑO, M.L.M., ARENA, A.H. and CHIOSSONE, T., 2008. Global corruption report 2008: corruption in the water sector. Cambridge: Cambridge University Press. Water Integrity Network Transparency International, Berlín, Report No. 363.61 G562 2008.

TOLMASQUIM, M., 2007. Plano Nacional de energia 2030. Brasília: Conselho Nacional de Politica Energetica.

TOLMASQUIM, M.T., 2014. Perspectivas e planejamento do setor energético no Brasil. Estudos Avançados, vol. 26, no. 74, pp. 247-260. http://dx.doi.org/10.1590/S0103-40142012000100017.

TUNDISI, J.G., 2007. Explosão do potencial hidrelétrico da Amazônia. Estudos Avançados, vol. 59, no. 59, pp. 109-117. http://dx.doi.org/10.1590/S0103-40142007000100009.

WAGLEY, C., 1974. Man in the Amazon. Bloomington: University Presses of Florida.

WELCOMME, R.L., 1999. A review of a model for qualitative evaluation of exploitation levels in multi-species fisheries. Fisheries Management and Ecology, vol. 6, no. 1, pp. 1-19. http://dx.doi. org/10.1046/j.1365-2400.1999.00137.x.

WELCOMME, R.L., COWX, I.G., COATES, D., BÉNÉ, C., FUNGE-SMITH, S., HALLS, A. and LORENZEN, K., 2010. Inland capture fisheries. Philosophical Transactions of the Royal Society of London. Series B, Biological Sciences, vol. 365, no. 1554, pp. 2881-2896. http://dx.doi.org/10.1098/rstb.2010.0168. PMid:20713391

WINEMILLER, K.O., MCINTYRE, P.B., CASTELLO, L., FLUET-CHOUINARD, E., GIARRIZZO, T., NAM, S., BAIRD, I.G., DARWALL, W., LUJAN, N.K., HARRISON, I., STIASSNY, M.L.J., SILVANO, R.A.M., FITZGERALD, D.B., PELICICE, F.M., AGOSTINHO, A.A., GOMES, L.C., ALBERT, J.S., BARAN, E., PETRERE, M., ZARFL, C., MULLIGAN, M., SULLIVAN, J.P., ARANTES, C.C., SOUSA, L.M., KONING, A.A., HOEINGHAUS, D.J., SABAJ, M., LUNDBERG, J.G., ARMBRUSTER, J., THIEME, M.L., PETRY, P., ZUANON, J., VILARA, G.T., SNOEKS, J., OU, C., RAINBOTH, W., PAVANELLI, C.S., AKAMA, A., SOESBERGEN, A. and SAENZ, L., 2016. Balancing hydropower and biodiversity in the Amazon, Congo, and Mekong. Science, vol. 351, no. 6269, pp. 128129. http://dx.doi.org/10.1126/science.aac7082. PMid:26744397.

WORM, B., BARBIER, E.B., BEAUMONT, N., DUFFY, J.E., FOLKE, C., HALPERN, B.S., JACKSON, J.B.C., LOTZE, H.K., MICHELI, F., PALUMBI, S.R., SALA, E., SELKOE, K.A., STACHOWICZ, J.J. and WATSON, R., 2006. Impacts of biodiversity loss on ocean ecosystem services. Science, vol. 314, no. 5800, pp. 787-790. http://dx.doi.org/10.1126/science.1132294. PMid: 17082450

ZARFL, C., LUMSDON, A.E., BERLEKAMP, J., TYDECKS, L. and TOCKNER, K., 2014. A global boom in hydropower dam construction. Aquatic Sciences, vol. 77, no. 1, pp. 161-170. http:// dx.doi.org/10.1007/s00027-014-0377-0.

ZHONG, Y. and POWER, G., 1996. Environmental impacts of hydroelectric projects on fish resources in China. Regulated Rivers: Research and Management, vol. 12, no. 1, pp. 81-98. http://dx.doi.org/10.1002/(SICI)1099-1646(199601)12:1<81::AIDRRR378>3.0.CO;2-9. 
Appendix A. Study sites, archive number of interviews deposited at the Fisheries and Food Institute (2015), Santos, SP, at Unisanta, Santos, SP.

The grant \# and funding agency is shown.

\begin{tabular}{|c|c|c|}
\hline ARCHIVE NUMBER/FIFO $^{1}$ & STUDY SITE & FUNDING AGENCY \\
\hline \multirow[t]{3}{*}{ PAJUR 007} & ALTO JURUÁ ACRE AM & FAPESP 1998/02619-8/ \\
\hline & & Project F. MacArthur 92/21848 \\
\hline & & Coords. Brown, Almeida \& Cunha (UNICAMP) \\
\hline \multirow[t]{2}{*}{ PDRPTO 008} & TOCANTINS RIVER AM & R. P.: FAPESP [1994/6258-7] CNPq [400.185/95-4] \\
\hline & & TO: 1987/ 1988: THEMAG/ELETROBRAS \\
\hline PTOCETNO 008 & TOCANTINS RIVER AM & TO: 1987/ 1988: THEMAG/ELETROBRAS \\
\hline PTOCGOMA 008 & TOCANTINS RIVER AM & TO: 1987/ 1988: THEMAG/ELETROBRAS \\
\hline PDDARA 009 & ARAGUAIA RIVER AM & FAPESP [1996/1036-1] \\
\hline PARA 009 & ARAGUAIA RIVER AM & FAPESP [1996/1036-1] \\
\hline PDRNMA 018 & QUEST RIO NEGRO AM & FAPESP 1998/16160-5 \\
\hline
\end{tabular}

${ }^{1}$ Fisheries and Food Institute. 


\section{Erratum}

In the article "Fish consumption on the Amazon: a review of biodiversity, hydropower and food security issues", DOI: https://doi.org/10.1590/1519-6984.186572, published ahead of print on Oct 29, 2018 in Brazilian Journal of Biology, in the Acknowledgements the article:

Where it reads:

Acknowledgements

We are very grateful to FAPESP grants (14/24994-8 and in the Appendix) as well as to the collaborative project (authors AB, DD, JP): “Managing links between hydropower development, fish and foods" funded by ANU's Brazilian Regional Reference Group Collaboration Scheme (Australia). We thank CNPq for productivity scholarships to A.B., N.H. and R.A.M.S.

It should be read:

Acknowledgements

We are very grateful to FAPESP grants (14/24994-8 and in the Appendix) as well as to the collaborative project (authors AB, DD, JP): "Managing links between hydropower development, fish and foods" funded by ANU's Brazilian Regional Reference Group Collaboration Scheme (Australia). We thank CNPq for productivity scholarships to A.B., N.H. and R.A.M.S.

In memoriam Benedito D. do Amaral. 